Modern Islamic Political Thought 
Macmillan International College Editions will bring to university, college, school and professional students, authoritative paperback books covering the history and cultures of the developing world, and the special aspects of its scientific, medical, social and economic development.

The International College programme contains many distinguished series in a wide range of disciplines, some titles being regionally biased, others being more international. Library editions will usually be published simultaneously with the paperback editions.

Titles of Related Interest:

A. Gamble: An Introduction to Modern Social and Political Thought

W. Husaini: Islamic Environmental Systems Engineering 


\section{Modern Islamic Political Thought}

The Response of the Shī'i and Sunnī Muslims to the

Twentieth Century

Hamid Enayat 
(C) Hamid Enayat 1982

All rights reserved. No part of this publication may be reproduced or transmitted, in any form or by any means, without permission.

First published 1982 by

THE MACMILLAN PRESS LTD

London and Basingstoke

Companies and representatives throughout the world

ISBN 978-0-333-27969-4 ISBN 978-1-349-16765-4 (eBook)

DOI 10.1007/978-1-349-16765-4

Typeset by Vantage Photosetting Co. Ltd., Southampton and London

The paperback edition of this book is sold subject to the condition that it shall not, by way of trade or otherwise, be lent, re-sold, hired out, or otherwise circulated without the publisher's prior consent in any form of binding other than that in which it is published and without a similar condition including this condition being imposed on the subsequent purchaser. 
To Anna, Hādi and Āmeneh 


\section{Contents}

Preface

Acknowledgements

On Transcription, Dates, etc.

Introduction: The relevance of the past $\quad 1$

1 Shī'issm and Sunnīsm : conflict and concord 18

I The spirit of Shī'ism 18

II The Polemics $\quad 30$

2 The crisis over the Caliphate 52

3 The concept of the Islamic state $\quad 69$

I Muhammad Rashīd Rị̣ā $\quad 69$

II Fundamentalism $\quad 83$

4 Nationalism, democracy and socialism 111

I Nationalism 111

$\begin{array}{lr}\text { II Democracy } & 125\end{array}$

$\begin{array}{lr}\text { III Socialism } & 139\end{array}$

5 Aspects of Shīi modernism $\quad 160$

$\begin{array}{ll}\text { Background } & 160\end{array}$

$\begin{array}{ll}\text { I Constitutionalism } & 164\end{array}$

$\begin{array}{ll}\text { II Taqiyyah } & 175\end{array}$

$\begin{array}{ll}\text { III Martyrdom } & 181\end{array}$

References $\quad 195$

$\begin{array}{ll}\text { Index } & 213\end{array}$ 


\section{Preface}

This book describes and interprets the major political ideas among Muslims in the twentieth century, particularly those expressed by the Egyptians and Iranians - but also a few writers and thinkers in Pakistan, India, Lebanon, Syria and Iraq. It is a book concerned mainly with ideas: history and sociology have been called to aid only on those occasions when they help to illuminate the background of thoughts. But what needs more emphasis is that it is a book concerned not so much with ideas set forth by Muslims, as with those which are Islamic-that is to say, are articulated in the recognised terms and categories of Islamic jurisprudence, theology and related disciplines, however much they may sound 'unorthodox' or unconventional. This naturally leaves out a great many Muslim intellectuals who may deserve serious study in other perspectives, but it arises from the conviction that in any effort to understand, let alone criticise, Muslim contributions to the political debates of our time, the procedure by which a thinker has arrived at an idea should be given as much weight as the idea itself. It is not enough to extol a writer for his brave new ideas without first ascertaining the extent to which his credal, epistemological and methodological premises have ensured the continuity of Islamic thought. Otherwise, one is apt to allow fascination with novelty to keep oneself from differentiating what is germane from what is extraneous to Islamic culture. The question of any ulterior or hidden motive that these authors may have harboured has been kept out of the analysis, not only because a thorough examination of them threatens to turn a history of ideas into histoire événementielle, but also because ideas seem to have a life of their own: people, especially those of the generations subsequent to the authors', often tend to perceive ideas with little or no regard for the authors' insidious designs, unless they are endowed with a capacity for mordant cynicism.

The book starts with an introduction outlining the way in which the traditional heritage has impinged on the development of modern thoughts, or can make them cogent and appealing to religious-minded audiences. This is followed by a study of the political differences between the two main schools or sects in Islam - Shi' 'ism and Sunnism, and especially on the twofold process of conflict and concord between them. The main intention is to show that the relationship between the two has been slowly changing in 
recent times, at least in the realm of political doctrines, from confrontation to cross-sectarian fertilisation. This approach later re-emerges at several other points of the book, with more examples of the implicit or explicit convergence between the two. The remaining chapters are devoted to two basic themes and their ramifications: the concept of the Islamic State from the time it was revived after the abolition of the Caliphate in Turkey in the 'twenties till the late 'seventies, and the Muslim response to the challenge of the alien, modern ideologies of nationalism, democracy and socialism.

Contemporary Islamic political thought cannot be properly appreciated without a knowledge of that set of doctrinal reformulations and reinterpretations which has now come to be known as Islamic modernism. Since a fair number of books have been published in various European languages on this once-promising movement, discussion of it in the present study has been kept to the minimum - with the exception of Shī'i modernism, which, having been neglected until recently, is treated in some detail in the concluding chapter. Instead, there has been some concentration on the lesser known but equally or potentially important authors.

The amount of political writing and pamphleteering within strictly Islamic framework, and even in the few countries mentioned above, is still staggering, and a student looking for broad trends and patterns has no option but to take some individual writers as representatives of whole schools of thought. This inevitably opens the arena for critics who might point to other writers and publications presenting different standpoints in order to disprove or question some of the conclusions reached in this book. But such criticisms, however unfair they might be, will be welcome in so far as they bring to light still more facets of the mental efforts of Muslims in their strivings for freedom and progress. 


\section{Acknowledgements}

I am indebted to a number of my colleagues and friends who read the draft of this book and made useful comments for its improvement. Albert Hourani and John Gurney read the whole of the draft, and spent considerable time discussing its content with me. I particularly benefited from stimulating conversations with Professor Madelung, and my compatriot, Husayn Mudarresī Țabāțabā' $\overline{1}$, who commented on the Introduction, and the chapters on Shì 'îsm. Michael Cook and Roger Owen made helpful criticisms respectively on Sunn̄i-Shī'i polemics and the chapter on 'Nationalism, Democracy and Socialism'. So did Nikki Keddie on the section dealing with Constitutionalism in Chapter 5. However, responsibility for any controversial opinions or inaccuracies in the text is entirely mine. Mrs Angela Turnbull, of Macmillan Press editorial staff, gave me valuable help in making the transliterations and the dates consistent.

I must thank the Tahereh Research Centre for Contemporary Iranian History for their support from October 1979 to March 1980, when I was working on this book. I am also grateful to the staffs of the Libraries of the Middle East Centre of St Antony's College, Oxford, the Oriental Room of the Bodleian Library, and the School of Oriental and African Studies, University of London, for their patient and unfailing services.

The original idea of this book would never have been conceived were it not for my friendship with the late Murtaḍa Muțahharī, Professor of Islamic Philosophy at Tehran University, a most original and creative thinker, a dedicated Muslim, and a humanist.

\section{On the System of Transcription, Dates, etc.}

For the sake of consistency, Arabic and Persian words have been transliterated both according to the same system, except that the vowel of the Arabic definite article has been given the value ' $u$ ' in Persian names and 
words (hence Faḍlullāh instead of Faḍl Allāh), and the consonantal vāv has been rendered as ' $v$ ' for Persian and ' $w$ ' for Arabic words. The main consideration throughout has been to convey exact phonetic structure. Some inconsistencies have, however, inevitably occurred either because of the necessity of observing the common usage, or in quotations, or owing to the different systems of transliterating Turkish words.

Most years before the sixteenth century have been given according to both the lunar Islamic calendar and the Christian calendar, separated by a stroke. The years after that have been given in the text only according to the Christian calendar.

Translations of the Qur'ānic verses are from J. M. Rodwell, The Koran (London, 1861), unless they are paraphrased.

H.E. 